\title{
ANALISIS MOTIVASI KERJA DAN KINERJA TENAGA KEPENDIDIKAN (STUDI KASUS DI UNIVERSITAS ALMA ATA TAHUN 2016)
}

\section{ANALYSIS OF WORK MOTIVATION AND EDUCATION PERFORMANCE (CASE STUDY AT ALMA ATA UNIVERSITY 2016)}

\author{
Sari Budiarti \\ Universitas Alma Ata Yogyakarta \\ E-mail: sari.budiarti88@gmail.com
}

\begin{abstract}
ABSTRAK
Kegiatan internship ini bertujuan untuk mengetahui motivasi kerja dan kinerja tenaga kependidikan di Universitas Alma Ata Yogyakarta. Permasalahan yang dihadapi belum optimalnya motivasi kerja dan kinerja tenaga kependidikan yang berdampak terhadap kepuasan mahasiswa yang semakin menurun. Populasi dalam penelitian ini adalah tenaga kependidikan di Universitas Alma Ata Yogyakarta. Penentuan sampel dalam penelitian ini dilakukan secara purposive sampling yang menentukan subjek sesuai tujuan dengan pertimbangan bahwa tenaga pendidikan bagian administrasi akademik dan pengajaran sangat penting dalam memberikan pelayanan kepada mahasiswa. Jumlah tenaga kependidikan sebanyak 8 (delapan) orang. Metode analisis yang digunakan dalam menganalisis motivasi kerja dan kinerja menggunakan metode survei, yang dilakukan dengan memberikan kuesioner kepada responden untuk menjawab pernyataan-pernyataan dalam kuesioner. Skala pengukuran menggunakan skala likert, kemudian data dianalisis dengan analisis deskriptif kuantitatif. Hasil analisis rerata motivasi kerja tenaga kependidikan menunjukkan bahwa motivasi kerja masih belum optimal. Hal ini dapat dilihat dari belum terpenuhinya kebutuhan fisiologis, kebutuhan akan rasa aman, kebutuhan akan penghargaan dan kebutuhan aktualisasi diri dalam teori Maslow. Hasil analisis rerata kinerja tenaga kependidikan menunjukkan bahwa kinerja masih belum optimal. Hal ini dapat dilihat dari belum optimalnya kuantitas, ketepatan waktu dan kemandirian tenaga kependidikan dalam menyelesaikan pekerjaan.
\end{abstract}

Kata Kunci: Motivasi Kerja, Kinerja.

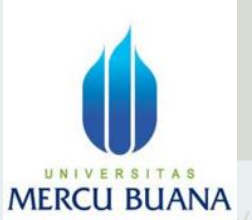

Jurnal Perilaku Dan Strategi Bisnis

Vol.8 No.1, 2020

Hal. $41-57$

\section{ABSTRACT}

This internship aims to determine the work motivation and performance case study of Alma Ata University Yogyakarta educational staffs at Alma Ata University. The problem faced not optimal educational staff's performance caused the decrease of college's satisfaction. The populations in this internship were educational staffs at Alma Ata University. Determination of the sample in this internship was conducted by purposive sampling which determines the subject according to the objective with the consideration that the educational staffs are very important in providing services to students. The number of educational staff is 8 (eight) people. The analytical method used in analyzing the motivation and performance survey 
method, conducted with respondents fill out the questionnaire using the Likert Scale and then analyzed using quantitative descriptive. The results of the analysis of average work motivation of employees demonstrate that work motivation is still not optimal. It can be seen from the not yet satisfy the physiological needs, safety needs, the needs of the award and the need for self-actualization in the theory of Maslow. The results of the analysis of the average performance of employees demonstrate that performance is still not optimal. It can be seen from the inadequate quality, quantity, timeliness and independence of employee in finishing the job.

\section{Keywords: Work Motivation, Performance.}

\section{PENDAHULUAN}

Di era globalisasi ini semakin banyak masyarakat yang menyadari akan pentingnya pendidikan formal khususnya pendidikan tinggi. Banyak masyarakat yang memberikan kesempatan kepada putra-putrinya untuk melanjutkan pendidikan ke jenjang yang lebih tinggi, keadaan ini didukung oleh adanya pilihan yang beragam perguruan tinggi yang ada di Indonesia baik milik negara maupun swasta. Hal ini pula yang menjadi peluang bagi perguruan tinggi khususnya swasta untuk dapat mengakomodir keinginan masyarakat dalam menghasilkan sumber daya manusia yang unggul.

Institusi pendidikan merupakan bentuk usaha di bidang jasa yang harus mampu menyediakan dan memberikan kualitas pelayanan yang baik kepada para mahasiswa. Kemampuan dalam memberikan kualitas pelayanan yang baik akan memberikan citra positif dimata mahasiswa sehingga mahasiswa akan merasa nyaman dalam melakukan aktivitas. Saat ini perkembangan perguruan tinggi di Indonesia dari tahun ke tahun semakin banyak dan menunjukkan perkembangan ke arah mutu yang lebih baik terhadap lulusan yang dihasilkan maupun dalam kualitas pelayanan yang diberikan.

Universitas Alma Ata merupakan institusi pendidikan yang bertujuan mencetak tenaga kesehatan yang unggul. Sebagai sebuah organisasi yang mempunyai keinginan mewujudkan Good University Governance, Universitas Alma Ata memerlukan SDM yang berkualitas. Keberhasilan suatu organisasi sangat dipengaruhi oleh kualitas SDM yang dimilikinya. Oleh karena itu, sumber daya manusia perlu dikelola dan dikembangkan secara terus menerus agar diperoleh sumber daya manusia yang berkualitas.

Dari pengamatan awal peneliti, indeks kepuasan mahasiswa terhadap tenaga kependidikan cenderung mengalami penurunan. Hal ini ditunjukkan pada tabel 1.1 di bawah ini.

Tabel 1. Tabel Kepuasan Mahasiswa terhadap Tenaga Kependidikan

\begin{tabular}{|c|c|c|c|}
\hline \multirow[t]{2}{*}{ No. } & \multirow[t]{2}{*}{ Aspek Penilaian } & \multicolumn{2}{|c|}{$\begin{array}{l}\text { Indeks } \\
\text { Kepuasar }\end{array}$} \\
\hline & & 2015 & 2016 \\
\hline 1 & Penampilan, keserasian, dan kerapian dalam berpakaian. & 3.01 & 2.84 \\
\hline 2 & Kecepatan dan ketepatan dalam memberikan pelayanan. & 2.53 & 2.34 \\
\hline 3 & Keramahan dalam memberikan pelayanan. & 2.78 & 2.59 \\
\hline 4 & Kesopanan dalam tingkah laku dalam memberikan & 2.92 & 2.67 \\
\hline 5 & Alur pengurusan Kartu Rencana Studi (KRS) & 2.60 & 2.45 \\
\hline 6 & $\begin{array}{l}\text { Alur pengurusan administrasi yang lain (legalisir, } \\
\text { pembuatan dokumen SKMK, transkrip, ijazah, dll) }\end{array}$ & 2.56 & 2.43 \\
\hline 7 & Pengaturan jadwal kuliah & 2.24 & 2.10 \\
\hline 8 & Perubahan kinerja dari semester sebelumnya ke semester & & \\
\hline & Ini & 2.54 & 2.44 \\
\hline & Rata-Rata Indeks Kepuasan & 2.65 & 2.48 \\
\hline
\end{tabular}

Sumber: Data Kantor Jaminan Mutu 
Dari data tersebut di atas dapat dilihat bahwa pada tahun 2016 indeks kepuasaan mahasiswa terhadap tenaga kependidikan sebagai berikut:

1. Dari aspek penampilan, keserasian dan kerapian dalam berpakaian pada tahun 2016 sebesar 2.84 mengalami penurunan sebesar 0.17 poin dari tahun 2015 .

2. Dari aspek kecepatan dan ketepatan dalam memberikan pelayanan pada tahun 2016 sebesar 2.34 mengalami penurunan sebesar 0.19 poin dari tahun 2015 .

3. Dari aspek keramahan dalam memberikan pelayanan pada tahun 2016 sebesar 2.59 mengalami penurunan sebesar 0.19 poin dari tahun 2015.

4. Dari aspek kesopanan dalam tingkah laku dalam memberikan pelayanan pada tahun 2016 sebesar 2.67 mengalami penurunan sebesar 0.25 dari tahun 2015.

5. Dari aspek alur pengurusan KRS pada tahun 2016 sebesar 2.45 mengalami penurunan sebesar 0.15 poin dari tahun 2015.

6. Dari aspek alur pengurusan administrasi yang lain pada tahun 2.43 mengalami penurunan sebesar 0.13 poin dari tahun 2015.

7. Dari aspek pengaturan jadwal kuliah pada tahun 2016 sebesar 2.10 mengalami penurunan sebesar 0.14 poin dari tahun 2015.

8. Dari aspek penilaian perubahan kinerja pada tahun 2016 sebesar 2.44 mengalami penurunan sebesar 0.17 poin dari tahun 2015.

Berdasarkan tabel 1 di atas terindikasi bahwa dari 8 aspek penilaian untuk mengukur kepuasan mahasiswa pada tahun 2016 mengalami penurunan dari tahun 2015. Penurunan indeks kepuasan mahasiswa terhadap tenaga kependidikan diduga dipengaruhi oleh motivasi kerja dan kinerja.

Motivasi merupakan kekuatan yang ada dalam seseorang, yang mendorong perilakunya untuk melakukan tindakan. Motivasi seseorang bersifat fluktuatif, pada saat tertentu motivasinya tinggi, sedangkan pada situasi lain motivasinya rendah. Kinerja merupakan hasil kerja secara kualitas dan kuantitas dari seorang tenaga kependidikan terhadap tugas dan tanggung jawab yang diberikan kepadanya. Kinerja yang baik akan berdampak pada pelayanan yang diberikan kepada mahasiswa.

Berdasarkan pengamatan awal yang dilakukan mengenai motivasi kerja dapat dilihat beberapa hal sebagai berikut:

1. Penghasilan yang diterima belum sesuai dengan harapan.

2. Fasilitas lahan parkir yang belum memadai.

3. Sarana ibadah yang belum baik.

4. Kerja lembur tenaga kependidikan belum sepenuhnya dihargai dengan baik.

5. Kekhawatiran akan terjadinya PHK masih tinggi.

6. Lingkungan tempat kerja belum kondusif.

7. Tenaga kependidikan belum antusias dalam melaksanakan pekerjaan.

8. Kekhawatiran tenaga kependidikan akan kehidupan setelah pensiuan masih tinggi.

9. Tenaga kependidikan masih mengeluh dengan pekerjaan yang dilakukan.

10. Tenaga kependidikan belum menyelesaikan pekerjaan dengan tepat waktu.

11. Kerja sama antar tenaga kependidikanbelum terjalin dengan baik.

12. Kinerja tenaga kependidikan belum dinilai dengan baik.

13. Kesempatan tenaga kependidikan untuk mengembangkan potensinya masih rendah. Disamping motivasi kerja, kinerja tenaga kependidikan juga belum optimal.

Berdasarkan pengamatan yang dilakukan mengenai kinerja dapat dilihat beberapa hal sebagai berikut:

1. Kinerja tenaga kependidikan mengalami penurunan.

2. Inovasi kerja tenaga kependidikan masih rendah.

3. Tenaga kependidikan kurang bersemangat dalam menyelesaikan pekerjaan.

4. $\quad$ Tanggung jawab tenaga kependidikan terhadap tugas yang diberikan masih kurang 
5. Penyelesaian kerja masih menunggu perintah atasan.

Mengingat masalah motivasi kerja dan kinerja merupakan masalah yang krusial dalam menunjang keberhasilan tujuan suatu institusi termasuk Universitas Alma Ata Yogyakarta, maka internship ini menganalisis bagaimana motivasi kerja dan kinerja tenaga kependidikan di Universitas Alma Ata.

\section{Motivasi}

Menurut Soekidjo Notoatmodjo (2009: 115) menyatakan bahwa motivasi merupakan interaksi seseorang dengan situasi tertentu yang dihadapinya. Suparno (2015: 187) mengemukakan bahwa motivasi sesungguhnya adalah suatu kekuatan yang menyebabkan seseorang menghasilkan sesuatu sesuai dengan apa yang ia katakan, bukan sekedar janji dan keinginan saja.

\section{Teori Motivasi}

Maslow menggambarkan hierarki kebutuhan sebagai berikut:

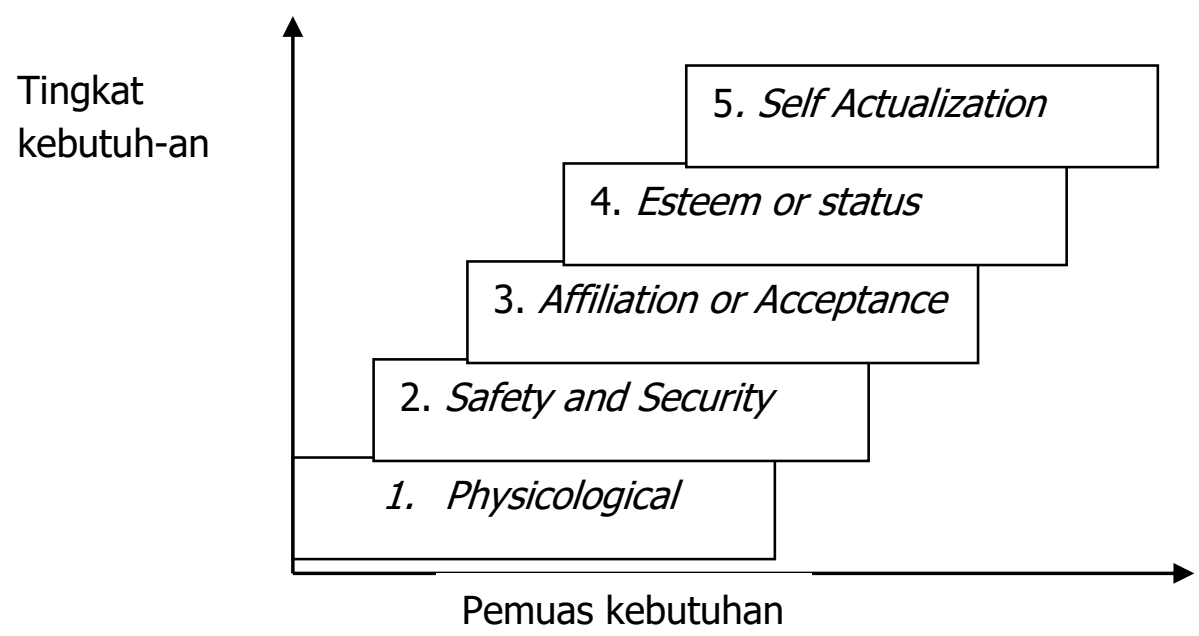

Gambar 1. Konsep hierarki kebutuhan menurut Maslow

Sumber: Malayu Hasibuan (2016:156)

\section{Kinerja}

Menurut Fatah Syukur (2012: 127) kinerja atau performance berarti tindakan menampilkan atau melaksanakan suatu kegiatan. Oleh karena itu, performance sering juga diartikan penampilan kerja atau perilaku kerja. Kinerja merupakan suatu kemampuan kerja atau prestasi kerja yang diperlihatkan oleh seorang pegawai untuk memperoleh hasil kerja yang optimal.

Secara etimologi, kinerja berasal dari kata prestasi kerja (performance). Sebagaimana dikemukakan oleh Mangkunegara dalam Suparno (2015: 131) bahwa istilah kinerja dari kata job performance atau actual performance (prestasi kerja atau prestasi sesungguhnya yang dicapai oleh seseorang) yaitu hasil kerja secara kualitas dan kuantitas yang dicapai oleh seorang pegawai dalam melaksanakan tugasnya sesuai dengan tanggungjawab yang diberikan padanya.

Pengukuran kinerja dapat dikelompokan kedalam 6 kategori yang digunakan untuk mengukur kinerja karyawan secara individual, sebagai berikut (Dessler dalam Teguh Suripto, 2015):

1) Kualitas: tingkat dimana hasil aktivitas yang dilakukan mendekati sempurna dalam arti menyesuaikan beberapa cara ideal dari penampilan aktivitas ataupun memenuhi tujuan yang diharapkan dari suatu aktivitas. 
2) Kuantitas: jumlah yang dihasilkan dinyatakan dalam istilah sejumlah unit dan jumlah siklus aktivitas yang diselesaikan.

3) Ketepatan waktu: tingkat suatu aktivitas yang diselesaikan pada waktu awal yang diinginkan, dilihat dari sudut koordinasi dengan hasil output serta memaksimalkan waktu yang tersedia untuk aktivitas lain.

4) Efektivitas: tingkat penggunanaan sumberdaya organisasi dimaksimalkan dengan maksud menaikkan keuntungan atau mengurangi kerugian dari setiap unit dalam penggunaan sumber daya.

5) Kemandirian: tingkat dimana seorang karyawan dapat melakukan fungsi kerjanya tanpa bantuan, bimbingan dari pengawas atau meminta turut campurnya pengawas guna menghindari hasil yang merugikan.

6) Komitmen kerja: tingkat dimana karyawan mempunyai komitmen kerja karyawan dan tanggung jawab karyawan terhadap perusahaan

\section{Faktor-faktor yang Mempengaruhi Kinerja}

Menurut Sedarmayanti dalam Suparno (2015), faktor-faktor yang mempengaruhi kinerja antara lain:

1) Sikap dan mental (motivasi kerja, disiplin kerja dan etika kerja).

2) Pendidikan.

3) Keterampilan.

4) Manajemen Kepemimpinan.

5) Tingkat penghasilan.

6) Gaji dan kesehatan.

7) Jaminan sosial.

8) Iklim kerja.

9) Sarana dan prasarana.

10) Teknologi.

11) Kesempatan berprestasi.

\section{METODE PENELITIAN Jenis Penelitian}

Jenis penelitian merupakan faktor penting dalam suatu penelitian. Jenis penelitian menunjang proses penyelesaian penelitian yang dilaksanakan. Penelitian ini dilakukan dengan melalui pendekatan deskriptif kuantitatif. Metode penelitian kuantitatif menurut Sugiyono (2011:8) menyatakan bahwa "metode penelitian kuantitatif dapat diartikan sebagai metode penelitian yang berlandaskan pada filsafat positivisme, digunakan untuk meneliti pada populasi atau sampel tertentu, pengumpulan data menggunakan instrumen penelitian, analisis data bersifat kuantitatif/statistik". Analisis deskriptif bertujuan untuk memberikaan deskripsi mengenai subjek penelitian berdasarkan data variabel yang diperoleh dari kelompok subjek yang diteliti (Saifuddin Azwar: 2007: 126). Metode ini dipilih agar dapat memberikan gambaran keadaan yang berkaitan dengan motivasi kerja dan kinerja tenaga kependidikan di Universitas Alma Ata Yogyakarta sebagai bahan dalam pengambilan keputusan manajerial dan organisasional.

\section{Subjek Penelitian}

Subjek penelitian dalam penelitian ini adalah tenaga kependidikan di Universitas Alma Ata Yogyakarta.

\section{Teknik Penyampelan}

Penentuan sampel dalam penelitian ini dilakukan secara purposive sampling yang menentukan subjek sesuai tujuan dengan pertimbangan bahwa tenaga pendidikan bagian 
administrasi akademik dan pengajaran sangat penting dalam memberikan pelayanan kepada mahasiswa. Jumlah tenaga kependidikan sebanyak 8 (delapan) orang

\section{Pengukuran Variabel}

Pengukuran variabel terhadap motivasi kerja dan kinerja tenaga kependidikan di Universitas Alma Ata dituangkan ke dalam kuesioner yang dikembangkan oleh penulis. Kuesioner disusun dalam bentuk daftar pernyataandan biasanya responden tinggal menjawab dengan memilih salah satu dari pilihan yang tersedia. Adapun kisi-kisi variabel tersebut adalah sebagai berikut:

Tabel 2. Kisi- kisi Variabel Motivasi Kerja

\begin{tabular}{|c|c|c|c|c|}
\hline No & Dimensi & Indikator & $\begin{array}{c}\text { Jumlah } \\
\text { Butir }\end{array}$ & $\begin{array}{c}\text { No } \\
\text { Butir }\end{array}$ \\
\hline 1. & Kebutuhan Fisiologis & $\begin{array}{l}\text { Kebutuhan secara } \\
\text { Fisik }\end{array}$ & 5 & $\begin{array}{l}1,2,3,4 \\
5\end{array}$ \\
\hline 2. & Kebutuhan Rasa Aman & $\begin{array}{l}\text { Keamanan fisik dan } \\
\text { Psikologis }\end{array}$ & 5 & $\begin{array}{l}6,7,8,9 \\
10\end{array}$ \\
\hline 3. & Kebutuhan Sosialisasi & Sosialisasi & 4 & $\begin{array}{l}11,12 \\
13,14\end{array}$ \\
\hline 4. & Kebutuhan akan Penghargaan & Prestise & 4 & $\begin{array}{l}15,16 \\
17,18\end{array}$ \\
\hline 5. & Kebutuhan Aktualisasi diri & $\begin{array}{l}\text { Pengembangan } \\
\text { Potensi }\end{array}$ & 4 & $\begin{array}{l}19,20 \\
21,22\end{array}$ \\
\hline
\end{tabular}

Sumber: Soekidjo Notoatmodjo (2009)

Tabel 3. Kisi-kisi Variabel Kinerja

\begin{tabular}{|c|c|c|c|c|}
\hline No & Dimensi & Indikator & $\begin{array}{l}\text { Jumlah } \\
\text { Butir }\end{array}$ & $\begin{array}{c}\text { No } \\
\text { Butir }\end{array}$ \\
\hline 1. & Kualitas & Hasil aktivitas & 3 & $1,2,3$ \\
\hline 2. & Kuantitas & Jumlah aktivitas & 2 & 4,5 \\
\hline 3. & $\begin{array}{l}\text { Ketepatan } \\
\text { Waktu }\end{array}$ & Waktu penyelesaian aktivitas & 2 & 6,7 \\
\hline 4. & Efektivitas & Penggunaan sumber daya & 2 & 8,9 \\
\hline 5. & Kemandirian & $\begin{array}{l}\text { Melakukan aktivitas tanpa } \\
\text { bantuan }\end{array}$ & 2 & 10,11 \\
\hline 6. & $\begin{array}{l}\text { Komitmen } \\
\text { Kerja }\end{array}$ & Komitmen dan tanggung jawab & 2 & 12,13 \\
\hline
\end{tabular}

Sumber: Teguh Suripto (2015)

\section{Data}

Menurut sumbernya, data penelitian digolongkan sebagai data primer dan data sekunder. Penelitian ini menggunakan data primer sebagai data utama yang akan dianalisis, sedangkan data sekunder sebagai data pendukung. Metoda pengumpulan data primer yaitu dengan metoda survei dengan instrumen pengumpul data yang digunakan adalah kuesioner yang diberikan kepada tenaga kependidikan sebagai subjek penelitian, sedangkan untuk data sekunder peneliti menggunakan dokumen-dokumen seperti gambaran umum Universitas Alma Ata Yogyakarta, struktur organisasi dan tugas pokok tenaga kependidikan.

\section{Metode Analisis}

Analisis data adalah upaya untuk mengolah data menjadi informasi sehingga karakteristik data tersebut dapat dipahami dan bermanfaat untuk solusi permasalahan, terutama masalah yang berkaitan dengan penelitian. Tujuan dari analisis data adalah mendeskripsikan fenomena yang terjadi di lapangan. 
Macam-macam teknik analisis data dalam penelitian diantaranya sebagai berikut (Saifuddin Azwar: 2007: 126):

1. Teknik analisis data secara deskriptif

Analisis deskriptif bertujuan untuk memberikan deskripsi mengenai subjek penelitian berdasarkan data dari variabel yang diperoleh dari kelompok subjek yang diteliti dan tidak dimaksudkan untuk pengujian hipotesis.

2. Teknik analisis data secara inferensial

3. Pengolahan data pada tingkat inferensial dimaksudkan untuk mengambil kesimpulan dengan pengujian hipotesis.

Teknik analisis data dalam penelitian ini menggunakan deskriptif kuantitatif yaitu dengan menghitung rata-rata dari masing-masing pernyataan. Skala pengukuran dalam kuesioner menggunakan skala likert. Skala likert dengan jawaban sangat tidak setuju, tidak setuju, netral, setuju dan sangat setuju. Skor jawaban kuesioner yang digunakan dalam penelitian ini adalah sebagai berikut:

$\begin{array}{llll}\text { STS } & =\text { Sangat Tidak Setuju } & \text { Skor } & =1 \\ \text { TS } & =\text { Tidak Setuju } & \text { Skor } & =2 \\ \text { N } & =\text { Netral } & \text { Skor } & =3 \\ \text { S } & =\text { Setuju } & \text { Skor } & =4 \\ \text { SS } & =\text { Sangat Setuju } & \text { Skor } & =5\end{array}$

\section{HASIL DAN PEMBAHASAN \\ Deskripsi Organisasi \\ Profil Universitas Alma Ata Yogyakarta}

Salah satu amanat yang tercantum dalam Pembukaan Undang-undang Dasar Negara Republik Indonesia Tahun 1945 adalah pemerintah Negara Indonesia berkewajiban untuk mencerdaskan kehidupan bangsa. Salah satu upaya untuk mewujudkan adalah dengan penyelenggaraan pendidikan. Pendidikan merupakan usaha sadar dan terencana untuk mewujudkan suasana belajar dan proses pembelajaran agar peserta didik secara aktif mengembangkan potensi dirinya untuk memiliki kekuatan spiritual keagamaan, pengendalian diri, kepribadian, kecerdasan, akhlak mulia, serta keterampilan yang diperlukan dirinya, masyarakat, bangsa dan Negara (UU Sisdiknas, 2003 pasal 1 ayat 1).

Pendidikan dapat diselenggarakan melalui dua jalur yaitu pendidikan formal dan pendidikan non formal. Jalur pendidikan formal diselenggarakan di sekolah yang melalui kegiatan belajar mengajar secara berjenjang dan berkesinambungan. Sedangkan jalur non formal atau di luar sekolah melalui kegiatan belajar dalam kehidupan langsung dengan masyarakat.

Perguruan tinggi memiliki peran yang sangat sentral dan strategis dalam pembangunan suatu bangsa karena disebabkan oleh dua hal yaitu pertama, lulusan perguruan tinggi akan memposisikan diri atau diposisikan masyarakat sebagai calon pemimpin, baik diperusahaan, masyarakat atau di instansi pemerintah; kedua, produk jasa pemikiran perguruan tinggi dianggap berperan dalam menentukan konsep pembangunan bangsa

Universitas Alma Ata merupakan perguruan tinggi yang mencetak tenaga ahli di bidang kesehatan. Lulusan yang dihasilkan meliputi tenaga bidan, tenaga perawat dan ahli gizi. Dalam mencapai tujuan tersebut, Universitas Alma Ata tidak terlepas dari biaya untuk menyelenggarakan pendidikan. Terlebih karena bergerak di bidang kesehatan terdapat banyak sekali komponen biaya yang dikeluarkan. 
Sesuai dengan nilai luhur yang terkandung di dalam namanya, Alma Ata yang dilahirkan oleh para cendekiawan muslim dan ulama pesantren hard (ATA) di Indonesia untuk meneruskan risalah Nabi Muhammad SAW dengan mencetak sumberdaya manusia professional, menjunjung tinggi nilai-nilai keilmuan dan mengedepankan kaidah-kaidah ilmiah sebagai landasan setiap amal perbuatannya (ALIMA), berakhlak mulia, dan dengan berpegang teguh kepada nilai-nilai ajaran Islam mengabdi kepada kepentingan umat.

\section{Visi dan Misi Universitas Alma Ata}

Perguruan Tinggi Alma Ata di dalam menjalankan kegiatannya memiliki visi dan misi sebagai berikut:

\section{Visi}

Pada tahun 2025, Alma Ata menjadi Peguruan Tinggi yang unggul, mandiri, dan dengan berpegang teguh kepada nilai-nilai ajaran Islam mengabdi untuk kepentingan umat.

\section{Misi}

1) Menyelenggarakan pendidikan, penelitian dan pengabdian kepada masyarakat (Tridharma Peguruan Tinggi) yang bermutu tinggi, dan berorientasi kepada kepentingan umat.

2) Mengembangkan sistem dan atmosfer akademik yang kondusif bagi terselenggaranya Tridharma Perguruan Tinggi melalui pengembangan sarana-prasarana akademik, sumber daya manusia dan tata kelola perguruan tinggi yang baik (good university governance) secara bertahap dan berkesinambungan.

\section{Tujuan}

1) Menjadi Perguruan Tinggi yang unggul, berkarakter Islami, dan berorientasi kepada kepentingan umat.

2) Menjadi Perguruan Tinggi yang mandiri dan mempunyai tata kelola yang baik.

3) Menghasilkan lulusan yang professional, bervisi global, dan ber-akhlak mulia.

\section{Daftar Uraian Pekerjaan Tenaga Kependidikan}

Perincian Tugas:

1) Bertanggung jawab terhadap terwujudnya sistem informasi akademik yang efektif di lingkungan Perguruan Tinggi (PT) Alma Ata.

2) Bertanggung jawab terhadap manajerial data akademik di Perguruan Tinggi Alma Ata.

3) Membantu kelancaran kegiatan akademik dan pengajaran di lingkungan Perguruan Tinggi Alma Ata.

4) Bertanggungjawab terhadap semua laporan terkait sistem informasi akademik.

5) Melaksanakan tugas lain atas perintah/ petunjuk pimpinan Perguruan Tinggi dan Ketua Yayasan Alma Ata.

6) Melaporkan segala kegiatannya secara periodik kepada pimpinan Perguruan Tinggi dan Ketua Yayasan Alma Ata

\section{Deskripsi Data}

Pengambilan data primer penelitian tentang analisis motivasi kerja dan kinerja tenaga kependidikan, berdasarkan sebarannya adalah sebagai berikut:

Tabel 4. Tabulasi Sebaran Kuesioner

\begin{tabular}{clcc}
\hline No & Keterangan & $\begin{array}{c}\text { Jumlah } \\
\text { Kuesioner }\end{array}$ & Prosentase \\
\hline 1. & Distribusi kuesioner & 8 & - \\
2. & Kuesioner kembali & 8 & 100
\end{tabular}


Sumber: data primer yang diolah

3. Kuesioner diolah $\quad 8 \quad 100$

Berdasarkan sebaran data variabel umum dalam penelitian tentang analisis motivasi kerja dan kinerja tenaga kependidikan, dapat digambarkan sebagai berikut:

Tabel 5. Data Responden Berdasarkan Jenis Kelamin

\begin{tabular}{ccccc}
\hline No & \multicolumn{2}{c}{ Jenis Kelamin } & Frekuensi & Prosentase \\
\hline 1. & Laki-laki & 5 & 62.5 \\
2. & Perempuan & 3 & 37.5 \\
\cline { 2 - 4 } Sumber: & \multicolumn{2}{c}{ Jumlah } & $\mathbf{8}$ & $\mathbf{1 0 0}$ \\
\cline { 2 - 4 }
\end{tabular}

Dari 8 responden tenaga kependidikan $62.5 \%$ adalah berjenis kelamin laki-laki dan $37.5 \%$ berjenis kelamin perempuan.

Tabel 6. Data Responden Berdasarkan Usia

\begin{tabular}{ccccc}
\hline No & & Usia & Frekuensi & Prosentase \\
\hline 1. & $15-30$ & 7 & 87.5 \\
2. & $31-45$ & 1 & 12.5 \\
3. & $46-60$ & 0 & 0 \\
\cline { 2 - 5 } & \multicolumn{2}{c}{ Jumlah } & $\mathbf{8}$ & $\mathbf{1 0 0}$ \\
\cline { 2 - 5 }
\end{tabular}

Sumber: data primer yang diolah

Berdasarkan usia, dari 8 responden tenaga kependidikan sebesar $87.5 \%$ berusia 15 30 tahun dan $12.5 \%$ berusia $31-45$ tahun.

Tabel 7. Data Responden Berdasarkan Masa Kerja

\begin{tabular}{cccc}
\hline No & Masa Kerja & Frekuensi & Prosentase \\
\hline 1. & $0-2$ & 1 & 12.5 \\
2. & $2-4$ & 4 & 50 \\
3. & $4-8$ & 3 & 37.5 \\
\hline & Jumlah & $\mathbf{8}$ & $\mathbf{1 0 0}$ \\
\hline
\end{tabular}

Sumber: data primer yang diolah

Berdasarkan masa kerja, sebesar $12.5 \%$ responden telah bekerja selama rentang $0-2$ tahun, sebesar $50 \%$ responden telah bekerja di Universitas Alma Ata selama rentang $2-4$ tahun, dan sebesar $37.5 \%$ bekerja selama rentang waktu $4-8$ tahun.

Tabel 8. Data Responden Berdasarkan Latar Belakang Pendidikan

\begin{tabular}{clccc}
\multicolumn{4}{c}{ Tabel 8. Data Responden } & Berdasarkan Latar Belakang Pendidikan \\
\hline & No & Masa Kerja & Frekuensi & Prosentase \\
\hline 1. & SMA / SMK & 3 & 37.5 \\
2. & DIII & 2 & 25 \\
3. & S1 & 2 & 25 \\
4. & S2 & 1 & 12.5 \\
\hline & & Jumlah & 8 & 100 \\
\hline
\end{tabular}

Sumber: data primer yang diolah

Berdasarkan latar belakang pendidikan, 37.5\% responden adalah lulusan SMA, 25\% responden lulusan DIII, $25 \%$ responden lulusan S1 dan $12.5 \%$ responden lulusan S2. 


\section{Hasil Analisis}

Rekapitulasi Hasil Tanggapan Responden Terhadap Analisis Motivasi Kerja Tenaga Kependidikan Universitas Alma Ata Yogyakarta.

Tabel 9. Rerata Motivasi Kerja

\begin{tabular}{|c|c|c|c|c|c|c|c|c|c|c|c|}
\hline & \multicolumn{11}{|c|}{ Daftar Pernyataan Motivasi Kerja } \\
\hline Resp & 1 & 2 & 3 & 4 & 5 & 6 & 7 & 8 & 9 & 10 & 11 \\
\hline \multicolumn{12}{|l|}{8} \\
\hline Mean & 3.63 & 4.00 & 2.50 & 3.13 & 3.13 & 3.63 & 4.25 & 3.38 & 3.75 & 2.88 & 4.38 \\
\hline \multicolumn{12}{|c|}{ Daftar Pernyataan Motivasi Kerja } \\
\hline Resp & 12 & 13 & 14 & 15 & 16 & 17 & 18 & 19 & 20 & 21 & 22 \\
\hline 8 & & & & & & & & & & & \\
\hline Mean & 4.25 & 4.25 & 4.38 & 3.38 & 3.88 & 3.25 & 3.75 & 3.63 & 3.63 & 3.38 & 3.38 \\
\hline
\end{tabular}

Analisis rerata motivasi kerja tenaga kependidikan di Universitas Alma Ata Yogyakarta dengan 22 butir pernyataan berdasarkan teori Motivasi Maslow dalam Soekidjo Notoatmodjo (2009) diperoleh hasil sebagai berikut:

a. Penghasilan yang saya terima sesuai dengan yang saya harapkan (butir 1).

Hasil penelitian butir 1 mendapat nilai 3.63 ini artinya bahwa penghasilan yang diterima oleh tenaga kependidikan belum sesuai dengan yang diharapkan.

b. Tempat kerja saya menyediakan waktu untuk istirahat (butir 2).

Hasil penelitian butir 2 mendapat nilai 4.00 ini artinya bahwa tenaga kependidikan mendapat waktu untuk istirahat.

c. Fasilitas lahan parkir memadai (butir 3).

Hasil penelitian butir 3 mendapat nilai 2.50 ini artinya bahwa fasilitas lahan parkir yang tersedia belum memadai.

d. Sarana beribadah tersedia dengan baik (butir 4).

Hasil penelitian butir 4 mendapat nilai 3.13 ini artinya bahwa sarana beribadah yang tersedia belum baik.

e. Kerja lembur saya dihargai dengan baik (butir 5).

Hasil penelitian ini butir 5 mendapat nilai 3.13 ini artinya bahwa kerja lembur yang dilakukan oleh tenaga kependidikan belum dihargai dengan baik.

f. Saya bekerja tanpa ada rasa terancam terkena PHK (butir 6).

Hasil penelitian butir 6 mendapat nilai 3.63 ini artinya bahwa dalam bekerja, tenaga kependidikan masih ada kekhawatiran terancam terkena PHK.

g. Keselamatan kerja sudah dijamin oleh lembaga (butir 7).

Hasil penelitian butir 7 mendapat nilai 4.25 ini artinya bahwa keselamatan kerja tenaga kependidikan sudah dijamin oleh perusahaan.

h. Lingkungan tempat kerja kondusif untuk melaksanakan pekerjaan (butir 8).

Hasil penelitian butir 8 mendapat nilai 3.38 ini artinya bahwa lingkungan tempat kerja belum kondusif untuk melaksanakan pekerjaan.

i. $\quad$ Saya antusias terhadap pekerjaan yang saya lakukan (butir 9).

Hasil penelitian butir 9 mendapat nilai 3.75 ini artinya bahwa tenaga kependidikan belum antusias dalam melakukan pekerjaannya.

j. Saya tidak merasa khawatir dengan masa pensiun setelah tidak bekerja lagi (butir 10). 
Hasil penelitian butir 10 mendapat nilai 2.88 ini artinya bahwa tenaga kependidikan merasa khawatir dengan masa pensiun setelah tidak bekerja lagi.

k. Saya menjalin kerjasama yang baik dengan rekan kerja saya (butir 11).

Hasil penelitian butir 11 mendapat nilai 4.38 ini artinya bahwa tenaga kependidikan dapat menjalin kerjasama yang baik dengan sesama rekan kerja.

I. Rekan kerja dapat menerima saya dengan baik (butir 12).

Hasil penelitian butir 12 mendapat nilai 4.25 ini artinya bahwa diantara tenaga kependidikan dapat saling menerima rekan kerjanya dengan baik.

m. Saya membantu rekan kerja yang mengalami kesulitan (butir 13).

Hasil penelitian butir 13 mendapat nilai 4.25 ini artinya bahwa diantara tenaga kependidikan dapat saling membantu rekan kerjanya yang mengalami kesulitan.

Saya ikut berpartisipasi dalam kegiatan sosial yang dilakukan lembaga (butir 14). Hasil penelitian butir 14 mendapat nilai 4.38 ini artinya bahwa tenaga kependidikan ikut berpartisipasi dalam kegiatan sosial yang dilakukan perusahaan.

n. Saya tidak mengeluh dengan pekerjaan saya (butir 15).

Hasil penelitian butir 15 mendapat nilai 3.38 ini artinya bahwa tenaga kependidikan masih mengeluh dengan pekerjaannya.

o. Saya berhasil menyelesaikan pekerjaan saya dengan tepat waktu (butir 16).

Hasil penelitian butir 16 mendapat nilai 3.88 ini artinya bahwa tenaga kependidikan belum menyelesaikan pekerjaannya dengan tepat waktu.

p. Prestasi karyawan dinilai dengan baik (butir 17).

Hasil penelitian butir 17 mendapat nilai 3.25 ini artinya bahwa prestasi kerja tenaga kependidikan belum dinilai dengan baik.

q. Pihak lembaga peduli dengan prestasi kerja karyawan (butir 18).

Hasil penelitian butir 18 mendapat nilai 3.75 ini artinya bahwa prestasi kerja tenaga kependidikan belum diperhatikan dengan baik.

r. Saya mendapat peluang untuk berinovasi dalam melaksanakan pekerjaan (butir 19). Hasil penelitian butir 19 mendapat nilai 3.63 ini artinya bahwa tenaga kependidikan belum mendapat peluang untuk berinovasi dalam melaksanakan pekerjaan.

s. Saya mendapat kesempatan untuk mengembangkan kemampuan kerja saya (butir 20).

Hasil penelitian butir 20 mendapat nilai 3.63 ini artinya bahwa tenaga kependidikan belum mendapat kesempatan untuk mengembangkan kemampuan kerjanya.

Saya mendapatkan kesempatan untuk memperoleh kenaikan jabatan (butir 21). Hasil penelitian butir 21 mendapat nilai 3.38 ini artinya bahwa tenaga kependidikan belum mendapatkan kesempatan untuk memperoleh kenaikan jabatan.

t. $\quad$ Perusahaan mendukung peningkatan karier saya (butir 22).

Hasil penelitian butir 22 mendapat nilai 3.38 ini artinya bahwa peningkatan karier tenaga kependidikan belum didukung dengan baik.

Rekapitulasi Hasil Tanggapan Responden Terhadap Analisis Kinerja Tenaga Kependidikan Universitas Alma Ata Yogyakarta

Tabel 10. Rerata Kinerja

\begin{tabular}{cccccccc}
\hline \multicolumn{8}{c}{ Daftar Pernyataan Kinerja } \\
\hline Resp & $\mathbf{1}$ & $\mathbf{2}$ & $\mathbf{3}$ & $\mathbf{4}$ & $\mathbf{5}$ & $\mathbf{6}$ & $\mathbf{7}$ \\
8 & & & & & & & \\
Mean & 4.13 & 4.25 & 3.38 & 3.75 & 3.75 & 3.50 & 3.38 \\
\hline \multicolumn{8}{c}{ Daftar Pernyataan Kinerja } \\
\hline Resp & $\boldsymbol{8}$ & $\mathbf{9}$ & $\mathbf{1 0}$ & $\mathbf{1 1}$ & $\mathbf{1 2}$ & $\mathbf{1 3}$ &
\end{tabular}




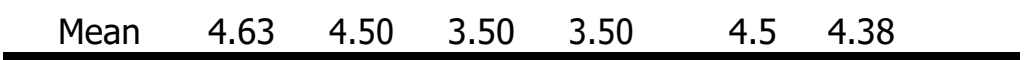 \\ Sumber: data primer yang diolah}

Analisis rerata kinerja tenaga kependidikan di Universitas Alma Ata Yogyakarta dengan 13 butir pernyataan penjabaran teori Dessler dalam Teguh Suripto (2015) diperoleh hasil sebagai berikut:

a. Kreativitas yang tinggi membantu saya mencapai hasil kerja yang tinggi (butir 1). Hasil penelitian butir 1 mendapat nilai 4.13 ini artinya bahwa kreativitas tinggi yang dimiliki dapat membantu tenaga kependidikan mencapai hasil kerja yang tinggi.

b. Saya menguasai tugas saya, sehingga hasil yang dicapai memuaskan (butir 2). Hasil penelitian butir 2 mendapat nilai 4.25 ini artinya bahwa tenaga kependidikan dapat menguasai tugas yang diberikan.

c. Saya berinovasi dengan cara kerja saya agar tercapai prestasi kerja yang tinggi (butir 3). Hasil penelitian butir 3 mendapat nilai 3.38 ini artinya bahwa tenaga kependidikan belum berinovasi dengan cara kerjanya.

d. Saya dapat menyelesaikan beberapa pekerjaan sekaligus (butir 4).

Hasil penelitian butir 4 mendapat nilai 3.75 ini artinya bahwa tenaga kependidikan belum dapat menyelesaikan beberapa pekerjaan sekaligus.

e. $\quad$ Saya bersemangat dalam menyelesaikan tugas-tugas baru (butir 5).

Hasil penelitian butir 5 mendapat nilai 3.75 ini artinya bahwa tenaga kependidikan belum bersemangat dalam menyelesaikan tugas-tugas baru.

f. Saya dapat menyelesaikan tugas yang diberikan atasan sebelum diminta (butir 6). Hasil penelitian butir 6 mendapat nilai 3.50 ini artinya bahwa tenaga kependidikan menyelesaikan tugas yang diberikan atasan setelah diminta.

g. Saya berusaha menyelesaikan tugas lebih awal agar dapat mengerjakan tugas lainnya (butir 7). Hasil penelitian butir 7 mendapat nilai 3.38 ini artinya bahwa tenaga kependidikan belum menyelesaikan tugas lebih awal agar dapat mengerjakan tugas lainnya.

h. Saya dapat memanfaatkan fasilitas yang ada dengan sebaik-baiknya (butir 8). Hasil penelitian butir 8 mendapat nilai 4.63 ini artinya bahwa tenaga kependidikan dapat memanfaatkan fasilitas yang ada dengan baik.

i. Dengan sarana kerja yang ada, saya dapat menyelesaikan tugas dengan baik (butir 9). Hasil penelitian butir 9 mendapat nilai 4.50 ini artinya bahwa tenaga kependidikan dapat memanfaatkan sarana kerja yang ada untuk menyelesaikan tugasnya dengan baik.

j. Dalam menyelesaikan tugas, saya bekerja tanpa menunggu perintah atasan (butir 10). Hasil penelitian butir 10 mendapat nilai 3.50 ini artinya bahwa tenaga kependidikan masih menunggu perintah atasan dalam menyelesaikan tugasnya.

k. Saya tetap fokus pada tugas saya meskipun atasan sedang pergi (butir 11).

Hasil penelitian butir 11 mendapat nilai 3.50 ini artinya bahwa tenaga kependidikan masih butuh pengawasan atasan dalam melaksanakan tugasnya.

I. Saya melaksanakan tugas dengan penuh tanggung jawab agar berhasil secara maksimal (butir 12). Hasil penelitian butir 12 mendapat nilai 4.50 ini artinya bahwa tenaga kependidikan dapat melaksanakan tugas dengan penuh tanggung jawab agar berhasil secara maksimal.

m. Saya bekerja sesuai dengan standar mutu yang telah ditetapkan (butir 13).

Hasil penelitian butir 13 mendapat nilai 4.38 ini artinya bahwa tenaga kependidikan bekerja sesuai dengan standar mutu yang telah ditetapkan. 


\section{Pembahasan}

\section{Motivasi Kerja Tenaga Kependidikan di Universitas Alma Ata Yogyakarta}

Hasil penelitian yang dilakukan penulis menunjukkan bahwa motivasi kerja tenaga kependidikan di Universitas Alma Ata dengan dimensi yang mempengaruhi terdiri dari kebutuhan fisiologis, kebutuhan rasa aman, kebutuhan sosialisasi, kebutuhan akan penghargaan dan kebutuhan aktualisasi diri termasuk dalam kategori belum optimal.

Berdasarkan daftar pernyataan responden dalam penelitian yang berhubungan dengan motivasi kerja sejumlah 22 butir pernyataan, dari hasil data yang diolah terdapat 16 butir pernyataan yang nilai mean-nya di bawah 4.00 hal tersebut berarti bahwa:

a. Pernyataan nomor 1 tentang "Penghasilan yang saya terima sesuai dengan yang saya harapkan" mendapat nilai 3.63 artinya bahwa penghasilan yang diterima oleh tenaga kependidikan belum sesuai dengan yang diharapkan.

b. Pernyataan nomor 3 tentang "Fasilitas lahan parkir memadai" mendapat nilai 2.50 artinya lahan parkir yang tersedia belum memadai.

c. Pernyataan nomor 4 tentang "Sarana beribadah tersedia dengan baik" mendapat nilai 3.13 artinya sarana beribadah belum tersedia dengan baik.

d. Pernyataan nomor 5 tentang "Kerja lembur saya dihargai dengan baik" mendapat nilai 3.13 artinya kerja lembur tenaga kependidikan belum dihargai dengan baik.

e. Pernyataan nomor 6 tentang "Saya bekerja tanpa ada rasa terancam terkena PHK" mendapat nilai 3.63 artinya bahwa dalam bekerja tenaga kependidikan masih ada kekhawatiran terancam terkena PHK.

f. Pernyataan nomor 8 tentang "Lingkungan tempat kerja kondusif untuk melaksanakan pekerjaan" mendapat nilai 3.38 artinya lingkungan tempat kerja belum kondusif untuk melaksanakan pekerjaan.

g. Pernyataan nomor 9 tentang "Saya antusias terhadap pekerjaan yang saya lakukan" mendapat nilai 3.75 artinya bahwa tenaga kependidikan belum antusias dalam melakukan pekerjaannya.

h. Pernyataan nomor 10 tentang "Saya tidak merasa khawatir dengan masa pensiun setelah tidak lagi bekerja" mendapat nilai 2.88 artinya tenaga kependidikan masih merasa khawatir dengan masa pensiun setelah tidak lagi bekerja.

i. Pernyataan nomor 15 tentang "Saya tidak pernah mengeluh dengan pekerjaan saya" mendapat nilai 3.38 artinya tenaga kependidikan masih mengeluh dengan pekerjaannya.

j. Pernyataan nomor 16 tentang "Saya berhasil menyelesaikan pekerjaan saya dengan tepat waktu" mendapat nilai 3.88 artinya bahwa tenaga kependidikan belum menyelesaikan pekerjaannya dengan tepat waktu

k. Pernyataan nomor 17 tentang "Prestasi karyawan dinilai dengan teliti" mendapat nilai 3.25 artinya prestasi kerja tenaga kependidikan masih belum dinilai dengan teliti.

I. Pernyataan nomor 18 tentang "Pihak perusahaan peduli dengan prestasi kerja karyawan" mendapat nilai 3.75 artinya bahwa prestasi kerja tenaga kependidikan belum diperhatikan dengan baik.

m. Pernyataan nomor 19 tentang "Saya mendapat peluang untuk berinovasi dalam melaksanakan pekerjaan" mendapat nilai 3.63 artinya bahwa tenaga kependidikan belum mendapat peluang untuk berinovasi dalam melaksanakan pekerjaan.

n. Pernyataan nomor 20 tentang "Saya mendapat kesempatan untuk mengembangkan kemampuan kerja saya" mendapat nilai 3.63 artinya bahwa tenaga kependidikan belum mendapat kesempatan untuk mengembangkan kemampuan kerjanya

o. Pernyataan nomor 21 tentang "Saya mendapatkan kesempatan untuk memperoleh kenaikan jabatan" mendapat nilai 3.38 artinya tenaga kependidikan masih belum mendapatkan kesempatan untuk memperoleh kenaikan jabatan. 
p. Pernyataan nomor 22 tentang "Perusahaan mendukung peningkatan karier saya" mendapat nilai 3.38 artinya peningkatan tenaga kependidikan masih belum didukung secara maksimal.

Hasil penelitian yang dilakukan penulis menunjukkan bahwa ada kesamaan dengan penelitian yang dilakukan Frisca Widyananda (2012) tentang Model Analisis Kinerja Karyawan dan Pengaruhnya terhadap Kepuasan Nasabah pada BNI Syariah Cabang Malang yang menyimpulkan bahwa variabel kinerja karyawan dipengaruhi oleh 3 variabel yaitu komunikasi (X1), koordinasi (X2) dan motivasi kerja karyawan (X3). Semakin meningkatnya komunikasi, koordinasi dan motivasi kerja karyawan maka akan meningkatkan kinerja karyawan yang secara langsung berakibat pada meningktanya kepuasan nasabah.

Hasil penelitian ini juga didukung oleh penelitian yang dilakukan oleh Mohammad Rifky Bagus Pratama (2017) tentang Pengaruh Motivasi Kerja dan Kepuasan Kerja Karyawan (Studi pada Karyawan Giant Hypermarket Mall Olympic Garden Malang) yang menyimpulkan bahwa berdasarkan analisis deskriptif menunjukkan bahwa dengan andanya motivasi kerja dan kepuasan kerja yang berada pada tingkat kuat, didapatkan kinerja karyawan yang kaut pula.

\section{Kinerja Tenaga Kependidikan di Universitas Alma Ata Yogyakarta.}

Hasil penelitian yang dilakukan penulis menunjukkan bahwa Kinerja tenaga kependidikan di Universitas Alma Ata dengan dimensi kualitas, kuantitas, ketepatan waktu, efektivitas, kemandirian dan komitmen kerja termasuk dalam kategori belum optimal.

Berdasarkan daftar pernyataan responden dalam penelitian yang berhubungan dengan kinerja sejumlah 13 butir pernyataan, dari hasil data yang diolah terdapat 7 butir pernyataan yang nilai mean-nya di bawah 4.00 hal tersebut berarti bahwa:

a. Pernyataan nomor 3 tentang "Saya berinofasi dengan cara kerja saya agar tercapai prestasi kerja yang tinggi" mendapat nilai 3.38 artinya tenaga kependidikan belum berinofasi secara maksimal terhadap cara kerjanya agar tercapai prestasi kerja yang tinggi.

b. Pernyataan nomor 4 tentang "Saya dapat menyelesaikan beberapa pekerjaan sekaligus"mendapat nilai 3.75 artinya bahwa tenaga kependidikan belum dapat menyelesaikan beberapa pekerjaan sekaligus.

c. Pernyataan nomor 5 tentang "Saya bersemangat dalam menyelesaikan tugas-tugas baru" mendapat nilai 3.75 artinya bahwa tenaga kependidikan belum bersemangat dalam menyelesaikan tugas-tugas baru

d. Pernyataan nomor 6 tentang "Saya dapat menyelesaikan tugas yang diberikan atasan sebelum diminta" mendapat nilai 3.50 artinya tenaga kependidikan menyelesaikan tugas yang diberikan atasan setelah diminta.

e. Pernyataan nomor 7 tentang "Saya berusaha menyelesaikan tugas lebih awal agar dapat mengerjakan tugas lainnya" mendapat nilai 3.38 artinya tenaga kependidikan belum menyelesaikan tugas lebih awal agar dapat mengerjakan tugas lainnya.

f. Pernyataan nomor 10 tentang "Dalam menyelesaikan tugas, saya bekerja tanpa menunggu perintah atasan" mendapat nilai 3.50 artinya tenaga kependidikan masih menunggu perintah atasan dalam menyelesaikan tugasnya.Pernyataan nomor 11 tentang "Saya tetap fokus pada tugas saya meskipun atasan sedang pergi" mendapat nilai 3.50 artinya bahwa tenaga kependidikan masih butuh pengawasan atasan dalam melaksanakan tugasnya.

Hasil penelitian yang dilakukan penulis menunjukkan bahwa ada kesamaan dengan penelitian yang dilakukan Frisca Widyananda (2012) tentang Model Analisis Kinerja Karyawan dan Pengaruhnya terhadap Kepuasan Nasabah pada BNI Syariah Cabang Malang yang menyimpulkan bahwa variabel kinerja karyawan di pengaruhi oleh 3 variabel terikat 
yaitu komunikasi (X1), koordinasi (X2) dan motivasi kerja karyawan (X3). Jika salah satu dari variabel terikat tersebut tidak ada maka kinerja karyawan tidak dapat maksimal. Sehingga diperlukan saling ketergantungan antar variabel untuk dapat memberikan kinerja yang memuaskan.

Hasil penelitian ini juga didukung oleh penelitian yang dilakukan oleh Dwi Agung (2014) tentang Pengaruh Kualitas Layanan dan Kinerja karyawan terhadap Kepuasan Nasabah Koperasi Pondok Pesantren Mamba'ul Mubbasyirin Shiddiqiyyah Bojonegoro yang menyimpulkan bahwa kinerja karyawan secara individual berpengaruh terhadap kepuasan nasabah Koperasi Pondok Pesantren Mamba'ul Mubbasyirin Shiddiqiyyah Bojonegoro.

\section{KESIMPULAN \\ Kesimpulan}

Berdasarkan hasil penelitian yang telah peneliti lakukan mengenai analisis motivasi kerja dan kinerja tenaga kependidikan di Universitas Alma Ata Yogyakarta, maka dapat diambil kesimpulan sebagai berikut:

1. Motivasi kerja tenaga kependidikan di Universitas Alma Ata dengan dimensi yang mempengaruhi terdiri dari kebutuhan fisiologis, kebutuhan rasa aman, kebutuhan sosialisasi, kebutuhan akan penghargaan dan kebutuhan aktualisasi diri termasuk dalam kategori belum optimal. Hal ini berdasarkan pada hasil data yang diolah dari daftar pernyataan responden dalam penelitian yang berhubungan dengan motivasi kerja sejumlah 22 butir pernyataan, terdapat 16 butir atau $72.73 \%$ pernyataan yang nilai meamya di bawah 4.00.

2. Kinerja tenaga kependidikan di Universitas Alma Ata dengan dimensi kualitas, kuantitas, ketepatan waktu, efektivitas, kemandirian dan komitmen kerja termasuk dalam kategori belum optimal. . Hal ini berdasarkan pada hasil data yang diolah dari daftar pernyataan responden dalam penelitian yang berhubungan dengan kinerja sejumlah 13 butir pernyataan, terdapat 7 butir atau $53.85 \%$ pernyataan yang nilai meamya di bawah 4.00

3. Motivasi kerja tenaga kependidikan di Universitas Alma Ata yang belum optimal berpengaruh terhadap kinerja yang belum optimal, sehingga hal ini berdampak secara langsung pada penurunan kepuasan mahasiswa.

\section{Saran}

Berdasarkan hasil penelitian di atas maka peneliti mencoba menyampaikan saran terkait motivasi kerja dan kinerja tenaga kependidikan Universitas Alma Ata sebagai berikut:

1. Motivasi Kerja

Dari segi motivasi kerja, dimensi yang mempengaruhi motivasi kerja yang belum optimal adalah kebutuhan fisiologis, kebutuhan akan penghargaan dan kebutuhan aktualisasi diri. Untuk meningkatkan motivasi kerja diharapkan dapat mengoptimalkan pemenuhan ketiga kebutuhan tersebut. Adapun langkah-langkah yang perlu dilakukan adalah:

1) Kebutuhan fisiologis, yaitu dengan melakukan perbaikan terhadap fasilitas yang ada seperti lahan parkir yang memadai serta sarana ibadah yang lebih kondusif dapat menjadi motif dasar dari seseorang bersedia bekerja, menjadi efektif dan dapat memberikan kinerja yang tinggi bagi organisasi.

2) Kebutuhan akan rasa aman, yaitu dengan memberikan kesempatan kepada tenaga kependidikan yang sudah menyelesaikan masa kontrak untuk diangkat menjadi karyawan tetap dan diperlukan adanya program imbalan (program dana pensiun) sehingga kekhawatiran akan hari tua setelah tidak bekerja dapat berkurang.

3) Kebutuhan akan penghargaan 
Setiap karyawan memiliki prestasi masing-masing. Setelah pencapaian usaha mereka dinilai baik oleh organisasi dan atasan, mereka akan berkompetisi dalam menyelesaikan tugas dengan sebaik-baiknya,. Penilaian prestasi yang baik akan memancing mereka untuk terus giat menapaki bidangnya.

4) Kebutuhan aktualisasi diri

Peluang berkembang perlu diberikan agar tenaga kependidikan dapat mengembangkan kariernya. Dengan begitu, tumbuh motivasi kerja karyawan untuk memenuhi kebutuhan akan aktualisasi diri.

2. Kinerja

Dari segi kinerja, terdapat 4 dimensi yang menunjukkan kinerja tenaga kependidikan belum optimal, untuk itu harus diupayakan peningkatan. Adapun langkah-langkah yang perlu dilakukan adalah:

1) Kualitas, yaitu dengan cara mendorong setiap individu untuk mengembangkan potensi yang ada pada dirinya. Misalnya dengan mengikuti pelatihan-pelatihan yang sesuai dengan karakteristik tugas masing-masing tenaga kependidikan.

2) Kuantitas, yaitu dengan memberikan pemahaman terhadap deskripsi pekerjaan yang harus dilakukan sehingga mereka dapat mengerjakan pekerjaan secara cepat dan tepat sesuai dengan target yang ditentukan.

3) Ketepatan waktu, yaitu dengan menjadikan situasi kerja yang sistematis sehingga tidak terjadi tumpang tindih dalam melaksanakan pekerjaan, dengan begitu pekerjaan dapat diselesaikan sesuai dengan waktu yang telah ditetapkan.

4) Kemandirian, yaitu dengan menjadikan tenaga kependidikan sebagai partner, menghargai setiap hasil kerja yang telah dicapai sehingga mereka akan termotivasi bekerja meskipun tanpa pengawasan atasan.

\section{DAFTAR PUSTAKA}

Abdullah, Ma'ruf. (2014). Manajemen dan Evaluasi Kinerja Karyawan. Yogyakarta. Aswaja Pressindo.

Afrizal, Andi. (2015). Pengaruh Gaya Kepemimpinan terhadap Motivasi Kerja dan Kepuasan Kerja serta Dampak pada Kinerja Karyawan. JESI Volume V, No.2 Desember 2015.

Agung, Dwi. (2014). Pengaruh Kualitas Layanan dan Kinerja karyawan terhadap Kepuasan Nasabah Koperasi Pondok Pesantren Mamba'ul Mubbasyirin Shiddiqiyyah Bojonegoro. Tesis. Universitas Sebelas Maret 2014.

Azwar, Saifuddin. (2007). Metode Penelitian. Yogyakarta: Pustaka Pelajar.

Hasibuan, Malayu. (2016). Manajemen Sumber Daya Manusia Edisi Revisi. Jakarta: Bumi Aksara.

Notoatmodjo, Soekidjo. (2009). Pengembangan Sumber Daya Manusia. Jakarta: Rineka Cipta.

Pratama, Mohammad Rifky Bagus, Mochammad Al Musadieq, Gunawan Eko Nurtjahjono. (2017). Pengaruh Motivasi Kerja dan Kepuasan Kerja Karyawan (Studi pada Karyawan Giant Hypermarket Mall Olympic Garden Malang). JUrnal Administrasi Bisnis Volumen 47. No.1 Juni 2017.

Priyono dan Marnis. (2008). Manajemen Sumber Daya Manusia. Sidoarjo: Zifatama Publisher. 
Priyono. (2014). Manajemen Sumber Daya Manusia. Sidoarjo: Zifatama Publisher.

Priyono. (2007). Pengantar Manajemen. Sidoarjo: Zifatama Publisher.

Sondang, Siagian. (2012). Teori Motivasi dan Aplikasinya. Jakarta: Rineka Cipta.

Sugiyono. (2011). Metode Penelitian Kuantitatif, Kualitatif, dan R\&D. Bandung: Alfabeta.

Suripto, Teguh. (2015). Meningkatkan Kinerja Karyawan Melalui Expectancy Theory dalam Motivasi. JESI Volume V, No. 2 Desember 2015.

Miftah, Thoha. (2007). Perilaku Organisasi, Konsep Dasar dan Aplikasinya. Jakarta: PT. Raja Grafindo Persada.

Wahjono, Sentot Imam. (2015). Manajemen Sumber Daya Manusia. Jakarta: Salemba Empat.

Widodo, Eko Suparno. (2015). Manajemen Pengembangan Sumber Daya Manusia. Yogyakarta: Pustaka Pelajar.

Widyananda, Frisca. (2012). Model Analisis Kinerja Karyawan dan Pengaruhnya terhadap Kepuasan Nasabah pada BNI Syariah Cabang Malang. Jurnal Ekonomi Pembangunan Volume 10. No.2 Desember 2012. 